THURSDAY, JANUARY 6, 1916.

\section{MERIT AND REWARD.}

N several occasions last year, the Premier and other members of the Government said in the House of Commons that the services rendered by scientific men in connection with war problems had been of high national value. It was acknowledged in the same place last July that practically all the laboratories in the country had been placed at the disposal of the War Office, which had derived great benefit from advice and information received from the Royal Society, the National Physical Laboratory, the universities, and other bodies; and opportunity was then taken to convey the thanks of the Army Council to these scientific and learned bodies.

Recent events have indeed brought men of science into closer relationship with national affairs than ever before, and some attempts have been made to organise their efforts. We give elsewhere in this issue a list of scientific committees appointed by the Government and various societies to assist the country in the present crisis. It will be noticed that in most cases, whether of Government panels of consultants or committees of scientific societies, the services rendered are gratuitous. No particular publicity has been given to this fact; and the majority of people are, therefore, unaware that the best expert scientific and technical knowledge has thus been placed freely at the disposal of the Government. As most scientific work is done for the good of the community instead of the personal profit of the individual, it is usually assumed officially that no payment need be made for it. The reverse is the case in other professions, where expert advice is never expected unless adequate fees are forthcoming. We were given several notable examples of this in a statement issued by the Treasury a few days ago, showing the payments made to the Law Officers of the Crown since 1905. The total amount received by these officers during this period was nearly $250,000 l$. In the year 1912-13 Sir Rufus Isaacs received $16,762 l$. as Attorney-General, and in the year 1913-14 Sir John Simon was paid 14,303l. We are glad that attention has been directed to these generous emoluments for legal services, which are essentially non-productive and unprofitable; and we believe that when the public has been sufficiently enlightened as to the relative values of national work in law and science, a No. 24IO, VOL. 96] readjustment of the rewards made for it will be demanded.

We anticipated that the publication of the list of New Year Honours would show definite public recognition of the national importance of science by the award to a number of leading and representative scientific workers of the distinctions which the country has to bestow. It was reasonable to have this expectation, since, as we have said already, no payment is made to the men of science who have been called in to assist the State with expert advice and judgment. We have now the list of New Year Honours before us; and among the scores of names we do not find a single honour given specifically for scientific work. Several men of science engaged in Government departments, as well as leading surgeons and physicians, are selected for various honours, but outside what may be termed official circles, science is practically ignored.

Many of the honours are rightly given for valour or distinguished action during the present war, but the services rendered by scientific men in order to make the nation strong enough for battle on land or sea under modern conditions are forgotten. It would not be supposed, from the list of honours, that science had anything to do with the war, yet every branch of the Army, Navy, and Medical Services is dependent upon it; and there never was greater need than now of making the utmost use of all that science can offer. Chemists have directed the manufacture of high explosives and fine chemicals urgently needed, and have provided means of protection from poisonous gases; electricians have made it possible for aeroplanes and airships to use wireless telegraphy as a means of rapid communication of intelligence to field stations at a distance of thirty miles or so; mathematical research and physical experiment are responsible for the designs of our most stable aeroplanes; optical science gives our battleships range-finders which will enable ranges to be determined within fifty to a hundred yards at a distance of a dozen miles; and, thanks to the adoption of scientific methods, the incidence of disease among our troops in France has been far lighter than in any previous campaign. It would be easy to multiply these applications of science to modern warfare many times, but national recognition of them is still to be sought.

The honours list includes six new peers; and we are disappointed, rather than surprised, not to find the name of a representative of science among them, though no scientific men have been called to the peerage to fill the gaps caused by 
the deaths of Lord Kelvin, Lord Lister, and Lord Avebury. There are six new Privy Councillors, and three new members of the Privy Council in Ireland; and of the nine, all except one are, or have been, members of the House of Commons, including two Labour members. The total disregard thus shown to the power which scientific men can bring into the chief council of our Sovereign is characteristic of the political mind which advises his Majesty in the selection of men worthy of the honour. The work of science is unknown to political circles; and the road to the Privy Council is not through Burlington House or other centres where scientific men add their contributions to the store of knowledge by which alone can national greatness be ensured, but through Parliament and the market-place, where distinction is not gained by producing-power, but by persuasive rhetoric.

From the national point of view, the Privy Council should include many men of distinguished eminence in pure and applied science, whereas, now that Sir Henry Roscoe is dead, there is not a member of the Council who can be specially regarded as a representative of science. We suppose that this accounts for the fact that the committee of the Council appointed to administer the moneys voted by Parliament for the development of scientific and industrial research does not include a single man of science. Scientific and industrial experts constitute a council to advise the committee, but are naturally subordinate to it. In a State which used true standards of value, each of these experts would be a member of the Privy Council instead of being under the control of a committee which knows nothing whatever of the technical difficulties to be faced. In this country, under the pressure of public opinion, our ministers appoint advisory committees of men of science and engineers for war problems connected with the Ministry of Munitions, Admiralty, the Board of Trade, and other departments of State; but, whereas all the members of these committees would have been made Privy Councillors in Germany, not a single one is given the like honour here. Yet the Times can refer to "an exceedingly catholic selection of new Privy Councillors, among whom Mr. Will Crooks is perhaps the most notable and the nearest in accord with the spirit of the time."

We need not attach much importance to the phrase used by our contemporary; yet it is true of the world bounded by the political horizon, where votes count for more than genius. True also it is, and characteristic of the spirit of the time as embodied in the daily papers, that, so far as we have seen, not a single reference has been made to the almost complete absence of the names of scientific men from the list of honours, and the usual satisfaction has been expressed at the selection. The indifference thus shown to science, when all its resources are needed for the successful prosecution of the war in which we are engaged, and for the industrial conflict to follow it, makes us wonder whether our statesmen are capable of understanding what scientific work means to a nation. We live in a scientific age, yet we are governed by men who belong to a century ago; and in their hands, unfortunately for national dignity, lies the division of national honours and emoluments. "Honour and glory and power" are thus much easier won by engaging in politics or commerce than by a career devoted to science. All the benefits of modern civilisation are due to the achievements of science or inventions based upon them; but neither the multitude nor its masters in politics or industry are familiar with the names of the men whose work has provided the comforts and the strength of the present day. While this condition of things persists, science cannot reasonably hope that its meritorious services to the State will receive enlightened attention or just reward.

\section{THE BRITISH COAL-TAR INDUSTRY.}

The British Coal-Tar Industry: Its Origin, Development, and Decline. Edited by Prof. W. M. Gardner. Pp. ix +437. (London : Williams and Norgate, 19r5.) Price ros. $6 d$. net. $\mathrm{N}$ this volume Prof. Gardner has collected a 1 series of lectures and addresses delivered on the British coal-tar industry and allied subjects during the last fifty years. These discourses fall naturally into two categories, those delivered before the war and those dealing with the problem of the shortage of dyes arising from the war.

The first three lectures of the earlier series are, very appropriately, the Cantor Lectures of 1868 on the aniline or coal-tar colours by Sir William Perkin, the discoverer of mauve or aniline purple, the first synthetic dye. Successive discourses by other lecturers at first indicated a satisfactory development of the youthful industry in England and France, but in $188 \mathrm{I}$ a note of warning was sounded by Sir Henry Roscoe, the subject being indigo and its artificial production, when the lecturer pointed out that, while the raw materials of the synthetic dye industry were produced in England, the conversion of these crude substances into finished and valuable colours was very largely

$$
\text { NO. } 24 \mathrm{IO} \text {, VOL, 96] }
$$

